\title{
TEXTO E VIDA: ANTROPOLOGIA E HISTÓRIA
}

RIBEIRO, Darcy. 0 povo brasileiro. a formação e o sentido do Brasil . São Paulo: Companhio das Letras, $1995.470 \mathrm{p}$.

O povo brasileiro faz parte de uma trajetória de vida e é resultado de uma reflexão teórica de longos anos. Esse texto, escrito no Uruguai em 1964 durante o exílio de Darcy Ribeiro ( por razões políticas); reescrito durante trinta anos, oferecese ao leitor como testemunho do ensaísta, "homem de fé e de partido". Ao longo do prefácio, o autor vai retomando, de forma crítica, sua teoria da História, presente em: $O$ processo civilizatório, As Américas e a civilizacão, O dilema da América Latina, Os brasileiros: teoria do Brasil e Os índios e a civilizacão. Todos esses textos, trançados pelo antropólogo, pelo historiador, pelo escritor e pelo político militante, prepararam o surgimento do novo livro.

No sentido de explicitar a formação do povo brasileiro, o autor mostra-nos que, apesar das variadas matrizes étnicas, formadoras do povo brasileiro, com exceção de algumas microetnias tribais, os brasileiros "se sentem e se comportam como uma só gente” (p. 22). Essa idéia de uniformidade cultural e nacional não pode obscurecer "as disparidades, contradições e antagonismos que subsistem debaixo delas como fatores dinâmicos da maior importância" (p. 22). A compreensão desse quadro leva o autor a analisar o processo de gestação étnica que deu nascimento aos núcleos originais, formadores do povo brasileiro; a estudar as linhas de diversificação que plasmaram os nossos modos regionais de ser e a enfocar a propriedade fundiária e o regime de trabalho, sistemas institucionais em que o povo surgiu e cresceu. 
O livro, bem extenso, divide-se em quatro partes: "O Novo Mundo", "Gestação Étnica", "Processo Sociocultural" e "Os Brasis na História". Começando pelas matrizes étnicas, Darcy Ribeiro explicita o conflito entre índios e brancos em todos os níveis, evidenciando as visóes opostas entre as duas culturas; a selvageria da civilização através da guerra bacteriológica, dos enfrentamentos de forças, de maneira desproporcional, e o fracasso do projeto jesuítico no Brasil através de sua atuação negativa, ligada à ambigüidade frente aos índios e à Coroa.

$\mathrm{Na}$ análise do processo civilizatório, o autor reconhece os povos iberos como germinais. No Brasil, a ação colonizadora de Portugal não obteve "nem mesmo a façanha menor de gerar uma prosperidade generalizável à massa trabalhadora, tal como se conseguiu, sob os mesmos regimes em outras áreas" (p. 69).

No estudo da gestação étnica, o cunhadismo é visto como uma instituição que possibilitou a formação do povo brasileiro. Constituiu-se "do velho uso indígena de incorporar estranhos à sua comunidade". Essa instituição favoreceu a integração dos índios ao sistema mercantil de produção, operando como "agência civilizatória pela intermediação do escambo, trocando antigos europeus pelas mercadorias da terra" (p. 83). Foi também com base no cunhadismo que se estabeleceram "criatórios de gente mestiça". A ameaça aos interesses dos colonizadores pelo cunhadismo fez com que a Coroa portuguesa adotasse em 1532 o regime das donatarias.

Para a manutenção da mão-de-obra de subsistência, o cativeiro indígena predominou no primeiro século de colonização até o século XVI, suplantado pela escravidão negra. A mestiçagem deu origem aos brasilíndios ou mamelucos que propiciaram a expansão portuguesa "terra adentro". Esse fato não ocorreu sem inúmeros conflitos, pois os mamelucos tiveram que enfrentar a hostilidade de várias tribos indígenas. A dizimação de tribos inteiras transformou o índio "específico" ( com sua língua e sua etnia tribal) em "índio genérico", integrado à sociedade nacional.

Ainda em relação às matrizes étnicas, cabe-me assinalar a presença negra no Brasil, incorporada à economia brasileira na condição de mão-de-obra escrava, tratada com violência "desumanizadora e deculturadora de eficácia incomparável" (p. 118). No enfoque da transfiguração étnica são assinaladas as várias instâncias em que essa atuou: biótica, ecológica, econômica e psicocultural.

O estudo da gestação étnica dá origem às abordagens do processo sócio-cultural, da urbanização caótica, das relações entre classe, cor e preconceito e às questões atinentes à assimilação ou segregação e à ordem versus o progresso.

Depois de tratar das matrizes étnicas, passando pela análise aprofundada do processo sócio-cultural, o autor focaliza "Os Brasis na História". Na explicitação dessa História, assinale-se o fragmento do livro: "a história do Brasil é, por isso, a história dessa alternidade original e das que a ela se sucederam. É ela que dá nascimento à primeira civilização de âmbito mundial, articulando a América como assentamento, a África como a provedora de força de trabalho e a Europa como consumidor privilegiado e como sócio principal do negócio" (p. 278).

Considerando que a História ocorre nos quadros locais, "em lugar de um quadro geral da história brasileira", o antropólogo e historiador opta por apresentar o Brasil através das várias faces que constituem objeto de análise nos capítulos: "O Brasil crioulo", "O Brasil caboclo", "O Brasil sertanejo", "O Brasil caipira" e "Brasis sulinos".

Retomando, no final do livro, de forma sucinta,
REVISTA DE ESTUDOS DF UTTERATURA Belo Horizonte, v. 3, p. 187 - 204, out. 95 
suas teorias desenvolvidas em As Américas e a civilizaşão, Darcy Ribeiro compara-nos com outros povos latino-americanos que também estão "em fazimento". A crença no ser humano e no seu povo faz com que termine seu texto, vislumbrando uma "nova Roma" que necessita dominar a "tecnologia da futura civilização, para se fazer uma potência econômica, de progresso auto-sustentado" (p. 449). Se, por um lado, essa crença do autor nos possibilita pensar em uma saída para o Brasil e para o seu povo; por outro, nos traz o seguinte questionamento: como acreditar no futuro, se no passado e mesmo no presente nos converteram em "proletariado externo" (p.441), conforme mostrou o próprio autor?

Darcy Ribeiro, na busca de compreensão do sentido do Brasil, utiliza-se de uma vasta bibliografia nacional e estrangeira. No âmbito nacional, seu texto dialoga com outros, como os de Gilberto Freyre e os de Sérgio Buarque de Hollanda ( para citar apenas alguns) e com seus próprios textos de História e de Antropologia. Dessa forma, O povo brasileiro resgata a memória do autor através de sua ensaística históricoantropológica .

Por essa e por outras formas de diálogo, O povo brasileiro mantém a posição de uma Antropologia crítica que estuda o Brasil para transformá-lo. $\mathrm{Na}$ explicitação de nossa identidade e de nossa alteridade, o livro torna-se mais uma referência obrigatória, impulsionando a leitura crítica do Brasil, do processo de formação do seu povo, dos vários textos ensaísticos de que se valeu Darcy Ribeiro, incluindo aqui sua obra antropológica e até mesmo $O$ povo brasileiro.

Haydée Ribeiro Coelho

UFMG

\section{ALTAS SACANAGENS DE SEBASTIÃO NUNES}

NUNES, Sebastiōo. Sacanagem pura. Sabaró: Dubolso;Mazza, 1995. Somos todos assassinos. 3. ed. Sabará: Dubolso; Mazza, 1995.

O primeiro problema que se apresenta para o leitor de Sacanagem pura e sua contrapartida, Somos todos assassinos (Mazza e Ediçōes Dubolso), é sua indefinição genérica. Onde se deve incluir cada um dos volumes, além da classificação bastante ampla, dada pelo próprio autor, de prosa? Há de se convir que tal indicação não nos leva a lugar algum tendo em vista o conteúdo dos textos de Sacanagem pura e de Somos todos assassinos, já em terceira edição, ou tendo em consideração também sua perigrafia. Além de conter os dois livros, invertidos na forma de impressão, o volume apresenta outras novidades que chocam o leitor menos avisado, a começar pela variação dos nomes do autor: Sebunes Nastião, Sebastunes Nião, Senião Bastunes e, na capa correspondente a Somos todos assassinos, Sebastião Nunes. Esta variação que brinca com o próprio nome do autor antecipa a iconoclastia interna. Na verdade, há dois registros. Um deles, formal, legal, corresponde à parte técnica do livro, com indicação de edição e outros detalhes como revisão, diagramação, composição; dedicatórias; um in memoriam; copyright; endereço; a orelha do livro, com comentários de Fausto Wolff, Gilberto Vasconcelos, Anna Marina, Lívio Xavier, Lázaro Barreto. Tudo isso é uma concessão à praxe, o preço pago por sua inserção num universo cujos valores são bem marcados e, pior que isso, cobrados.

O outro registro começa pelo subtítulo da obra Sacanagem pura, que é "Ensaios sacanas sobre publicidade". Portanto, saímos da indefinição da "prosa" para chegarmos à objetividade do ensaio. Os ensaios se autodefinem: sacanas.

REVISTA DE ESTUDOS DE LITERATURA Belo Horizonte, v. 3, p. $187-204$, out. 95 